\title{
GOOD ENGLISH PRONUNCIATION USERS AND THEIR PRONUNCIATION LEARNING STRATEGIES
}

\author{
MAGDALENA SZYSZKA \\ Opole University \\ mszyszka@uni.opole.pl
}

\begin{abstract}
The study investigates pronunciation learning strategies (PLS) deployed by those with good English pronunciation, as well as their beliefs concerning the variables that affect pronunciation competence. In order to collect data for analysis this study surveyed 61 participants who had learned English as a foreign language. They comprised 28 higher education teachers and scholars specialising in English phonetics and phonology, who were defined as good pronunciation users (GPU), and 33 EFL teacher training students, viewed as average pronunciation learners (APL). This cohort responded to a survey on pronunciation learning strategies and expressed their views on several aspects affecting the L2 pronunciation learning process. These aspects were: age of the first contact with L2 (age of onset), motivation, exposure to the target language, the teacher's pronunciation model, and learning strategies. The study used both open- and close-ended question formats to collect data from both GPU and APL. The analyses of the data helped to create a tentative profile of a successful L2 pronunciation learner.
\end{abstract}

\section{Introduction}

Good language learners have attracted scholarly attention, particularly since the 1970s. The results of the pioneering studies by Rubin (1975) and Stern (1975) revealed a number of effective language learning strategies (LLS) deployed by learners, who used them to enhance and support their foreign or second language (L2) learning processes appropriately. Subsequently, concern for exploiting effective ways of L2 learning triggered multifaceted research on LLS, for example, applied to listening, reading, oral communication, writing and vocabulary (cf. Cohen \& Macaro, 2007). However, relatively little is known about strategies for learning to pronounce English as a foreign language (Berkil, 2009; Eckstein, 2007; Osburne, 2003; Pawlak, 2008, 2010, 2011; Peterson, 2000). Even less is known about the types of pronunciation learning strategies (PLS) successful or good pronunciation users (GPU) deploy (Tominaga, 2009). These facts warrant investigating these strategies and analysing how they differ from PLS used by other L2 pronunciation learners, here termed average L2 pronunciation learners (APL).

Pronunciation acquisition is a long and daunting process that is affected by a number of variables. Zhang (2009) divides these variables into internal (biological, cognitive and psychological), and external (or influenced by the sociocultural and pedagogical contexts of L2 learning). 
Regarding learner internal variables, it is assumed that age, a biological factor, determines L2 pronunciation. However, researchers' views on the influence of age on pronunciation acquisition vary. Some studies confirm the hypothesis that younger learners (those who have not reached puberty) have a greater chance at acquiring nativelike pronunciation (e.g. Flege, Yeni-Komshian, \& Liu, 1999; Johnson \& Newport, 1989). Nevertheless, there is still research that rejects this assertion (e.g. Birdsong \& Molis, 2001; Bongaerts, van Summeren, Planken, \& Schils, 1997). Moyer (2014) gives an insightful discussion on the role of age in the acquisition of L2 pronunciation. She calls for taking individual learner differences, such as L2 experience, motivation, and learning approach, into account while researching the age factor in learning a new sound system.

Cognitive internal variables, according to Wrembel (2008), encompass, among others, language aptitude and learning strategies subsuming PLS, which are still underresearched (Berkil, 2009; Eckstein, 2007; Rokoszewska, 2012). The former is defined as "a variety of human traits that are involved in thinking, reasoning, processing information, and acquiring a new knowledge" (Dörnyei, 2005, p. 32). According to Carroll (1962 in Celce-Murcia, Brinton, Goodwin, \& Griner, 2010), language aptitude comprises phonetic coding ability, grammatical sensitivity, inductive language learning ability, and memory. Phonetic coding ability, in turn, is associated with appropriate discrimination of the target language sounds and making proper symbol-to-sound and sound-to-symbol associations. Thus, this ability might be strongly linked to L2 pronunciation learning. In Purcell and Suter's (1980) research, aptitude and ability to mimic are found among the strong predictors of second language pronunciation performance. Similarly, motivation, a psychologically conditioned internal variable discussed later, is hypothesised to influence the acquisition of target language pronunciation (Purcell \& Suter, 1980).

One of the external sociocultural variables affecting L2 pronunciation learning is one's first language. Its role in acquiring the target language segmentals and suprasegmentals cannot be overlooked. For example, many researchers (cf. CelceMurcia et al., 2010; Kenworthy, 1987; Purcell \& Sutter, 1980; Rogerson-Revell, 2011) have agreed that the differences between the phonological systems of L1 and L2 may either help or impede L2 pronunciation acquisition. In other words, certain L2 pronunciation errors may stem from L1. Finally, pronunciation instruction also belongs to the external pedagogical factors that influence pronunciation learning outcomes (e.g. Euler, 2014; Wrembel, 2003).

According to Rubin (1975), a good language learner uses a set of effective learning strategies. For example, he practises word pronunciation, tries to seek opportunities to communicate with native speakers, monitors his speech, pays attention to how his speech is received and how good it is according to standards, attempts to maximise intelligibility of speech, and places accurate intonation patterns over individual sounds. All of the above strategies refer to pronunciation, although the subjects of Rubin's study were good language learners, not good pronunciation learners or users. Further investigation focusing on a narrower group of successful EFL learners, good pronunciation users, might contribute to a better understanding of the L2 pronunciation 
learning process. The aim of the study is to analyse the views of good pronunciation users on variables they consider crucial in L2 sound system acquisition and look into their preferred strategies of L2 pronunciation learning.

\section{Variables associated with good $L 2$ pronunciation learners}

Brown (2008) discusses three variables associated with good language learners in pronunciation learning: motivation, aptitude, and opportunity. However, bearing in mind that "learners with strategic knowledge of language learning, compared with those without, become more efficient, resourceful, and flexible, thus acquiring a language more easily" (Tseng, Dörnyei, \& Schmitt, 2006, p. 78), one more factor might be added to the attributes of a good pronunciation learner: pronunciation learning strategies. Thus, four, instead of three, variables are discussed below.

Motivation is an individual learners' variable reported to affect the acquisition of target language pronunciation (cf. Celce-Murcia et al., 2010). Moyer (2004) associates motivation with conscious effort, intentionality, and planning toward a goal. Moreover, the concept is complex and dynamic, with several manifestations depending on the L2 learner's individual experience and goals (Dörnyei, 1998; Dörnyei 2005). Being extremely difficult to define and measure, motivation has been operationalised in various ways in order to corroborate its interplay with phonological attainment. For example, Moyer (1999) and Bongaerts, van Summeren, Planken, and Schils (1997) place professional orientation for L2 learning among the most important factors in explaining good pronunciation. Similarly, Moyer (2007) finds a significant correlation between the degree of a foreign accent and the desire to improve it. Both integrative and intrinsic motivations have also been reported to correlate positively with L2 learners' desires to sound native-like and the degree of foreign accent (Purcell \& Suter, 1980; Sardegna, Lee, \& Kusey, 2014; Smit, 2002). Good pronunciation learners, therefore, are described as strongly internally motivated (Brown, 2008).

Although aptitude is hypothesised "to be least subject to manipulation" (Rubin, 1975, p. 42), Brown (2008) claims that good pronunciation learners are aware of their aptitude for acquiring pronunciation via sound imitation, and in Purcell and Suter's (1980) research, aptitude for oral mimicry is the second best predictor of L2 pronunciation accuracy. Moreover, within Carroll's (1989, in Gass \& Selinker, 2008) construct of language aptitude, phonetic coding ability with auditory discrimination is directly connected with pronunciation. Therefore, while measuring aptitude, learners' abilities linked to pronunciation learning are considered. Consequently, learners with better skills in sound discrimination score higher in language learning aptitude. Similarly, Piske, MacKay and Flege (2001, p. 202) suggest that mimicry together with musical ability contribute to L2 learning aptitude. However, they are aware that the latter "has as yet not been identified as one of those variables that have an important influence on degree of L2 foreign accent." Mimicry has recently attracted the interest of some researchers (e.g. Hinton, 2013; Reiterer et al., 2011), who have found moderate positive correlations between pronunciation performance and abilities to mime sounds in the words and sentences of foreign languages. 
The next factor attributed to good pronunciation learners refers to the opportunity to use the target language. Rogerson-Revell (2011) views exposure to L2 as a critical factor in pronunciation learning. The drive for using the target language, operationalised as a need to converse with a native speaker, is the third predictor of pronunciation accuracy in Purcell and Suter's (1980) study. Moyer (2004) also recognises the important role of close contact with a native interlocutor in developing a target language sound system. Therefore, when L2 learners seek to communicate with native speakers and be exposed to the target language, a higher level of L2 pronunciation attainment may be hypothesised.

Pawlak (2010, p. 191) defines pronunciation learning strategies as "deliberate actions and thoughts that are consciously employed, often in a logical sequence, for learning and gaining greater control over the use of various aspects of pronunciation." In order to take these actions, pronunciation learners must be aware of them and be able to choose those which are most suitable and appropriate for their pronunciation learning process. The outcomes of studies on good language learners (Rubin, 1975; Stern, 1975) support the claim that good language learners use strategies consciously and apply them effectively. Thus, knowing more about the strategies applied by good pronunciation users may help less able pronunciation learners achieve better results.

Although PLS research and classifications are still in their infancy, some attempts to approach PLS categorisation have been made (Eckstein, 2007; Osburne, 2003; Pawlak, 2010; Peterson, 2000). For example, Peterson (2000) has followed Oxford's (1990) taxonomy, dividing PLS into memory, cognitive, compensation, metacognitive, affective and social, subsuming 12 PLS and 43 pronunciation learning tactics. The present study follows this taxonomy. Osburne (2003) has proposed 7 PLS, such as memory and imitation, paralanguage, individual words, global articulatory gesture, prosody and individual sounds. Eckstein (2007) has placed PLS within Kolb's learning cycle and its equivalent four pronunciation acquisition stages, whereas Pawlak (2010) has proposed four major PLS categories: cognitive, metacognitive, affective and social. Pawlak also emphasises that the list of PLS and tactics is an open question.

Moreover, preliminary results of research studies on the interplay of PLS and pronunciation attainment confirm positive correlations between some PLS and L2 articulation. For example, Eckstein (2007) has measured this relationship with a scale designed on the basis of Kolb's learning cycle, referring to four stages of pronunciation acquisition. The first one, concrete experience, is related to L2 input and pronunciation practice. The second one, reflection on observation, is linked to pronunciation noticing and feedback defined as an ability to understand and process an interlocutor's pronunciation. The next stage is an abstract conceptualisation entailing hypothesis forming, followed by the last stage, which is the action based on a new conceptualisation parallel to hypothesis testing. PLS were categorised within these stages and an instrument, the Strategic Pronunciation Learning Scale (SPLS), was designed to measure the frequency of PLS use. The participants, 183 international L2 learners of English in the United States, responded to the PLS survey. Their pronunciation achievement was calculated with a standardised speaking level achievement test (LAT). The results showed that 3 out of 28 PLS correlated positively with pronunciation performance: the strategies for noticing pronunciation mistakes, adjusting facial muscles while speaking, and asking for help with the pronunciation of new English words. 
Berkil (2009) has undertaken another attempt to investigate the correlation between PLS and three pronunciation proficiency groups. She examined the frequency of PLS through a Strategy Inventory for Learning Pronunciation (SILP), based on Oxford's (1990) taxonomy of language learning strategies. Pronunciation performance was elicited via passage reading and a free-response task where 40 participants expressed their views on one of five topics. The findings indicated that 3 out of 52 PLS were significantly correlated with pronunciation proficiency levels. Both the strategy of purposeful listening to sounds and listening to tapes, television, movies or music were used more frequently in the moderate pronunciation ability group than in the other groups. The moderate level pronouncers least frequently employed the third strategy of using phonetic symbols or self-devised codes to remember how to pronounce words.

Rokoszewska (2012) has investigated the interplay between PLS and perception, as well as production, of English vowels. The participants were 63 first-year English as a foreign language learners, who responded to a 5-point Liket scale questionnaire eliciting data on the frequency of PLS use. Rokoszewska measured production of English vowels with a vowel production test consisting in articulation of pure vowels and diphthongs, as well as reading both a set of minimal pairs and a selected text. The analysis of the results revealed a weak but significant positive correlation between the use of PLS and students' production of English vowels and diphthongs.

\section{Method}

The current study endeavours to arrive at a tentative profile of a good pronunciation user (GPU). Therefore, groups of both GPU and APL are surveyed to examine their use of PLS and to find out which variables, in their views, affect their pronunciation learning. Comparing and contrasting these two groups allows us to elicit variables exclusively characteristic of GPU. The responses to the following research questions help to outline the profile of a good pronunciation learner:

RQ1. What are the most and the least preferred PLS of GPU?

RQ2. What is the difference in PLS use among GPU and APL?

RQ3. Which factors, in the view of GPU, contributed to their English pronunciation learning success most?

\subsection{Participants}

A total number of 61 respondents took part in the survey. The good pronunciation users (GPU) were 28 higher education specialists in EFL participating in an international conference devoted to speech and accents. They had different mother tongues: Polish $(\mathrm{N}=17)$, Finnish $(\mathrm{N}=2)$, Czech $(\mathrm{N}=4)$, French $(\mathrm{N}=1)$, Spanish $(\mathrm{N}=1)$, Italian $(\mathrm{N}=1)$, Japanese $(\mathrm{N}=1)$, and Portuguese $(\mathrm{N}=1)$. The mean initiation age (age of onset) of EFL learning was 9.23, and before their academic studies they spent 4.5 months on average in English speaking countries. In this group there were 19 females and 7 males, 2 respondents did not declare their gender. Although the pronunciation attainment of these GPU was not directly evaluated, it is assumed that their perceptive and articulatory 
abilities were, beyond doubt, very advanced, since the participants in the international conference on phonetics and phonology were scholars specialising in the field. A sample of 33 average pronunciation learners (APL) was invited to respond to the survey in order to address one of the research questions. These were 32 Polish and 1 Ukrainian second and third year students studying EFL at a Teacher Training College in Poland. Like the GPU, they started learning English, on average, at the age of 9.48. However, unlike GPU, APL declared that they had spent only 0.6 of a month in a country where English is an official language. In this group, there were 23 female and 9 male respondents, 1 person did not indicate their gender.

\subsection{Instrument and procedure}

The instrument used was a questionnaire consisting of several parts. The first part referred to bio-data, eliciting gender, L1, the age at which L2 learning began, and time spent in an English-speaking country. The second part comprised open-ended questions, such as, What were/are your preferred ways of improving L2 pronunciation? The last part elicited quantitative data, of which 6 items reflected selected variables affecting L2 pronunciation: age of onset, exposure to L2 in class, exposure to L2 outside class, L2 teacher's model pronunciation, concern for L2 pronunciation and ways of learning pronunciation. The respondents used a 5-point Likert scale, from $1-$ not at all to $5-a$ lot, to indicate the degree to which they thought the variables had affected their pronunciation. Furthermore, 14 items in the questionnaire stated PLS (see Table 2). The participants were to mark how frequently they used them on a 5-point Likert scale, from 1 - never to 5 -always. These items represented memory ( 2 items), cognitive ( 8 items), metacognitive (1 items), affective (1 item) and social (2 items) PLS and were selected from the Pronunciation Learning Strategy Inventory (PLSI), the non-parametric instrument measuring PLS proposed by Berkil (2009). The PLSI consisted of 52 items, based on Oxford's (1990) LLS categories, and responding to the full version of it might take more than an hour. For this reason, only 14 PLS representing different categories werechosen to be included in the last part of the instrument.

The questionnaire was distributed among the GPU during the conference in December 2012. ${ }^{1}$ The respondents were requested to provide the data and most of them spent approximately 30 minutes to complete on the questionnaire. The same instrument was used to collect the responses from APL, who agreed to provide the answers during their classes. It also took them more-or-less 30 minutes to finish the questionnaire.

The data collected from the first part of the questionnaire were analysed qualitatively by delving into the GPU responses to open questions and categorising the reported PLS into memory, cognitive, compensation, metacognitive, affective and social strategies. Next, the quantitative part, concerning the role of the 6 variables influencing L2 pronunciation acquisition and the frequency of 14 PLS use, was analysed. For this purpose, basic statistical measures, such as means (M) and standard deviations (SD)

\footnotetext{
${ }^{1}$ I would like to express my gratitude to prof. Ewa Waniek-Klimczak, the conference organiser at Łódź University, who permitted the distribution of the questionnaire among the participants of the conference. I also thank all the conference participants who kindly agreed to respond to it.
} 
were used to account for GPU self-evaluation of selected variables affecting L2 pronunciation and PLS use. Additionally, t-tests for independent samples were calculated to indicate the differences between the GPU and the APL.

\subsection{Results}

The open format part of the questionnaire elicited GPU responses concerning the period of time during which their L2 pronunciation improved noticeably and their preferred ways and strategies of L2 pronunciation learning. There were 21 GPU who declared that there had been a specific period during which their L2 pronunciation improved considerably. The respondents frequently mentioned their university studies, courses in phonetics and phonology, as well as stays in English speaking countries as turning points in their L2 pronunciation progress. A few of them indicated the time they were in contact with skilled non-native and native-speaker teachers, whose pronunciation served as a model. Individual responses referred to periods of more intensive self-practice, greater access to English in the media, commencing phonetics teaching, and joining an English theatre group.

The total number of preferred strategies for pronunciation learning enumerated by GPU was 39, comprising 31 cognitive, 6 metacognitive, 1 memory and 1 affective strategies. The most frequently mentioned PLS focused on listening, favoured by 10 GPU, who valued listening not only to native speakers who provided a good model, but also to authentic songs and movies. Imitation and repetition took the second and third top places on the list of PLS deployed by GPU. As many as 9 GPU declared that mimicking native speaking interlocutors, actors/actresses and pop singers was their preferred way of improving articulation, whereas 6 respondents resorted to repetition of speech samples. Other preferred ways of pronunciation practice were talking to oneself and native speakers - mentioned by 6 GPU, singing songs and reading texts out loud the last two were chosen by 4 and 3 GPU respectively. In the group of metacognitive PLS 3 GPU liked either checking or studying pronunciation in a dictionary. Apart from the above strategies, individuals mentioned metacognitive strategies, such as teaching pronunciation, transcribing, following a notice-and-improve approach; one memory strategy, namely learning songs by heart; and one affective strategy: feeling good about correct pronunciation. 


\begin{tabular}{llllll}
$\begin{array}{l}\text { How far, in your opinion, } \\
\text { did the following aspects affect } \\
\text { your L2 pronunciation? }\end{array}$ & Min.Max. Mean & SD \\
\hline Age of onset & 1 & 5 & 3.64 & 1.36 \\
\hline Exposure to L2 in class & 1 & 5 & 3.52 & 1.01 \\
\hline Exposure to L2 outside class & 2 & 5 & 4.46 & 0.79 \\
\hline L2 teacher's model pronunciation & 1 & 5 & 3.81 & 1.03 \\
\hline Concern for L2 pronunciation & 1 & 5 & 4.74 & 0.85 \\
\hline Ways of learning pronunciation & 1 & 5 & 4.29 & 0.91 \\
\hline
\end{tabular}

Table 1. GPU self-evaluation of selected variables affecting L2 pronunciation.

The outcomes of the quantitative part of the questionnaire referring to variables affecting L2 pronunciation are shown in Table 1. The GPU found concern for L2 pronunciation highly influential $(\mathrm{M}=4.74)$. With respect to this factor, the group was almost unanimous, as indicated by the low level of standard deviation, .85. The second best predictor of good pronunciation was exposure to $\mathrm{L} 2$ outside the classroom ( $\mathrm{M}=4.46$, $\mathrm{SD}=.79$ ). Interestingly, none of the GPU marked this variable as 'not at all' influential. The respondents also appreciated ways of learning pronunciation $(\mathrm{M}=4.29, \mathrm{SD}=.91)$. In other words, GPU recognized the high value of a strategic approach to pronunciation learning.

Although all the averages of the answers concerning variables affecting L2 pronunciation were higher than 3.5, placing the influence of the selected variables higher than the mid-value between little and somewhat influential, the least appreciated aspects were $\mathrm{L} 2$ teacher's model pronunciation $(\mathrm{M}=3.81)$ and exposure to $\mathrm{L} 2$ in class $(\mathrm{M}=3.52)$. Moreover, although the mean value concerning the initial age of L2 learning was 3.64, the responses were more differentiated, with the standard deviation reaching 1.36.

Next, the responses to the 14 PLS included in the quantitative part of the questionnaire were analysed. The basic statistical data (means and standard deviations) were provided for both groups, GPU $(\mathrm{N}=28)$ and APL $(\mathrm{N}=33)$. Subsequently, t-tests were calculated to indicate the differences between GPU and APL in their use of PLS (see Table 2). The strategies often used in pronunciation learning were listening to tapes/television/movies/music ( $M=4.04)$, talking aloud/silently to oneself in English $(\mathrm{M}=3.93)$, and imitating native speakers $(\mathrm{M}=3.89)$. Not surprisingly, these results overlap with PLS noted as favourable in the open-ended part of the questionnaire. Furthermore, 5 other PLS were marked as used relatively frequently: concentrating intensely on pronunciation while speaking $(\mathrm{M}=3.54)$, seeking opportunities to talk with others in English $(\mathrm{M}=3.37)$, noticing different English dialects/varieties $(\mathrm{M}=3.36)$, mentally rehearsing how to say something before speaking $(\mathrm{M}=3.36)$, and asking someone else to correct one's pronunciation $(M=3.04)$. The PLS whose averages oscillated around 2 belonged to the affective group, imitating English sounds for fun $(\mathrm{M}=2.5)$, and memory group, using codes of symbols to remember pronunciation $(\mathrm{M}=2.57)$, categories. Such PLS like recording oneself to listen to one's pronunciation 
$(\mathrm{M}=1.93)$ and making up songs or rhymes to remember how to pronounce words $(\mathrm{M}=1.79)$ were used rarely.

\begin{tabular}{|c|c|c|c|c|c|}
\hline \multirow{2}{*}{ PLS } & \multicolumn{2}{|c|}{$\begin{array}{l}\text { GPU } \\
(\mathrm{N}=28) \\
\end{array}$} & \multicolumn{2}{|c|}{$\begin{array}{l}\text { APU } \\
(\mathrm{N}=33) \\
\end{array}$} & \multirow{2}{*}{$\mathrm{t}$} \\
\hline & Mean & SD & Mean & SD & \\
\hline I listen to tapes/television/movies/music a lot & 4.04 & 1.1 & 4.61 & 0.60 & $-2.54 *$ \\
\hline I talk aloud/silently to myself in English & 3.93 & 1.05 & 3.82 & 0.83 & 0.45 \\
\hline I imitate native speakers & 3.89 & 1.29 & 3.79 & 0.91 & 0.36 \\
\hline $\begin{array}{l}\text { I concentrate intensely on pronunciation while } \\
\text { speaking }\end{array}$ & 3.54 & 1.35 & 3.58 & 0.85 & -0.14 \\
\hline I seek opportunities to talk with others in English & 3.37 & 1.31 & 3.97 & 1.03 & -1.97 \\
\hline I notice different English dialects/varieties & 3.36 & 1.19 & 3.97 & 0.90 & -2.26 \\
\hline $\begin{array}{l}\text { I mentally rehearse how to say something before } \\
\text { speaking }\end{array}$ & 3.36 & 1.22 & 3.42 & 0.95 & -0.23 \\
\hline I ask someone else to correct my pronunciation & 3.04 & 1.4 & 2.82 & 1 & 0.70 \\
\hline $\begin{array}{l}\text { I read reference materials about English } \\
\text { pronunciation }\end{array}$ & 2.75 & 1.17 & 2.00 & 0.89 & $2.81 * *$ \\
\hline I form and use hypotheses about pronunciation & 2.64 & 1.06 & 2.06 & 0.91 & $2.23 *$ \\
\hline $\begin{array}{l}\text { I use a code of symbols to remember } \\
\text { pronunciation }\end{array}$ & 2.57 & 1.23 & 2.09 & 1.05 & 1.63 \\
\hline I imitate English sounds with L1 words for fun & 2.50 & 1.2 & 2.61 & 1.20 & -0.34 \\
\hline I record myself to listen to my pronunciation & 1.93 & 1.21 & 1.55 & 0.96 & 1.36 \\
\hline $\begin{array}{l}\text { I make up songs or rhymes to remember how to } \\
\text { say words }\end{array}$ & 1.79 & 0.96 & 2.12 & 0.91 & -1.30 \\
\hline
\end{tabular}

Table 2. Results of the t-test for independent samples measured for PLS used in the groups of GPU and APL (significant at $* \mathrm{p} \leq .05, * * \mathrm{p}<.001$ ).

To find significant differences in the frequency of use of PLS between GPU and APL, a t-test for independent samples was calculated. In the case of three PLS the differences between GPU and APL were significant. The strongest difference was seen in the use of a metacognitive strategy: reading reference materials about English pronunciation. Although GPU declared more frequent use of this strategy than APL, the average frequency of its use was not too high. Another metacognitive PLS, forming and using hypotheses about pronunciation, also turned out to be more frequently applied by GPU. However, quite surprisingly, APL declared significantly higher application of listening to authentic texts $(M=4.6)$ although the mean value calculated for GPU $(\mathrm{M}=4.03)$ indicated that this strategy was used by them very often. One of the possible explanations might be the fact that APL, as students of EFL, probably find more time to exploit authentic texts through available media, though they spend less time reading reference texts. 


\section{Discussion}

The aim of this study is to delineate a tentative profile of a good pronunciation user based on their PLS preferences and their views on factors that have contributed to their success in English pronunciation. GPU perceive the period of university studies as important for pronunciation improvement. During that time, they took pronunciation courses, worked in language laboratories, and attended lectures in phonology. Therefore, GPU believe that phonological competence and meta-competence, awareness-raising efforts play a considerable role in L2 pronunciation acquisition, whereas other learners of English, as investigated by Wrembel (2003), do not necessarily value these factors highly in determining L2 pronunciation. Interestingly, in the current study two PLS, forming and using hypotheses about pronunciation and reading reference materials about English pronunciation, are used significantly more frequently by GPU than APL. This finding supports GPU beliefs that instruction and awareness-raising are important in pronunciation learning.

Moreover, GPU recognize that exposure to L2 while staying in English speaking countries may largely affect L2 pronunciation, which goes in line with Brown's (2008) idea that the opportunity to use L2 is a factor attributed to good pronunciation learners. Naturally, being immersed in an L2 community provides numerous opportunities to focus on L2 pronunciation. They also believe that out-of-class exposure has a greater impact on L2 pronunciation than in-class exposure. Therefore, pronunciation trainers and teachers should encourage students to be sensitive to L2 pronunciation not only within the time allotted for classroom pronunciation practice, but also beyond. This might be done by setting interesting and involving tasks that may raise learners' motivation, because, like Moyer (1999) and Purcell and Suter (1980), GPU think that concern for L2 pronunciation largely affects pronunciation.

Additionally, GPU mostly agree that strategies of learning pronunciation contribute to English pronunciation learning success. Listening to L2 is their most frequently used strategy. Apart from listening-based strategies, PLS preferred by GPU belong to more active strategies, such as repetition, imitation, and singing songs, which require engagement in the production of speech on part of the learner. Moreover, they have a wide and individualised repertoire of PLS, for instance, talking to oneself in English, playing/having fun with pronunciation, transcribing, the spot-and-improve approach, and reading aloud. However, there are strategies that they avoid; these are, for example, recording their voices in order to listen to pronunciation and making up songs or rhymes to remember how to pronounce words. Perhaps these less preferred PLS are instances of very individual strategies and, being more time consuming, are less frequently used.

\section{Conclusions}

In order to the understand complex processes of L2 pronunciation acquisition, a range of empirical research approaches is needed. The experience of good pronunciation users, shared by expressing their views and favourable PLS, adds an invaluable dimension that may be developed in further studies on pronunciation learning and teaching. Moreover, the current study, though not devoid of limitations, generates some 
practical implications that might be exploited by teachers in L2 pronunciation training courses.

The results of the study, however, should be treated cautiously due to some limitations. For example, a larger number of GPU might be selected on the basis of their pronunciation performance, not professional qualifications. The questionnaire applied in the study contained only a limited number of PLS. Thus a broader repertoire of PLS, supplementing the instrument, might lead to further conclusions on pronunciation learning of the GPU and the APL. Interviews with the GPU might also add some valuable data.

Despite the constraints of the study, the outcomes support the claim that there is a need to raise motivation and concern for L2 pronunciation, for example, through motivational tasks and projects that support and develop learners' autonomous approaches. It is also paramount to encourage L2 pronunciation learners to focus on L2 segmental and suprasegmental aspects outside the classroom, thus maximising L2 exposure. Following PLS preferred by GPU, L2 learners may pay more attention to exploiting active L2 pronunciation learning strategies, such as imitation of native speakers. Finally, promoting L2 pronunciation awareness raising, for instance, through reading reference materials about English pronunciation, may be a worthwhile effort.

The study shows only a microscopic fragment of a bigger picture related to L2 pronunciation acquisition. There is definitely a need for further research into the individual differences of those who are successful in their L2 pronunciation attainment. Not only is a broader investigation into PLS of GPU pending, research into GPU internal, cognitive, psychological, external, social, and cultural factors, is also necessary to understand fully what determines L2 pronunciation learning success. 


\section{References}

Berkil, G. (2009). A Closer Look at Pronunciation Learning Strategies. Saarbrucken: VDM - Publishing.

Birdsong, D., \& M. Molis. (2001). On the evidence for maturational constraints in second-language acquisition. Journal of Memory and Language, 44, 1-15.

Bongaerts, T., van Summeren, C., Planken, B., \& Schils, E. (1997). Age and ultimate attainment in the pronunciation of a foreign language. Studies in Second Language Acquisition, 19, 447-465.

Brown, M. (2008). Good language learner and pronunciation. In C. Griffiths (Ed.), Lessons from good language learners (pp. 197-207). Cambridge: Cambridge University Press.

Celce-Murcia, M., Brinton, D. M., Goodwin, J. M., \& Griner, B. (2010). Teaching Pronunciation. A Course Book and Reference Guide. New York: Cambridge University Press.

Cohen, A. D., \& Macaro, E. (2007). Language learner strategies. Oxford: Oxford University Press.

Dörnyei, Z. (1998). Motivation in second and foreign language learning. Language Teaching 31: 117-135. doi:10.1017/S026144480001315X

Dörnyei, Z. 2005. The psychology of the language learner. Mahwah, NJ: Lawrence Erlbaum.

Eckstein, G. T. (2007). A correlation of pronunciation learning strategies with spontaneous English pronunciation of adult ESL learners. Unpublished master's thesis. Brigham Young University, Provo, Utah. Retrieved November 10, 2010, from http://contentdm.lib.byu.edu/ETD/image/etd1973.pdf.

Euler, S. S. (2014). Assessing instructional effects of proficiency-level EFL pronunciation teaching under a connected speech-based approach. Studies in Second Language Learning and Teaching, 4(3), 665-692. DOI: 10.14746/ssllt.2014.4.4.5

Flege, J. E., Yeni-Komshian, G., \& Liu, H. (1999). Age constraints on second language acquisition. Journal of Memory and Language, 41, 78-104.

Gass, S. M, \& Selinker, L. (2008). Second language acquisition: An introductory course. New York: Routlege.

Hinton, M. (2013). An Aptitude for Speech: The Importance of Mimicry Ability in Foreign Language Pronunciation. In E. Waniek-Klimczak \& L. R. Shockey (Eds.), Teaching and Researching English Accents in Native and Non-native Speakers, Second Language Learning and Teaching (pp. 103-111). Berlin Heidelberg: Springer-Verlag.

Johnson, J. S., \& Newport, E. L. (1989). Critical period effects in second language learning: the influence of maturational state on the acquisition of English as a second language. Cognitive Psychology, 21, 60-99.

Moyer, A. (1999). Ultimate attainment in L2 phonology: the critical factors of age, motivation, and instruction. Studies in Second Language Acquisition, 21, 81-108.

Moyer, A. (2004). Age, Accent, and Experience in Second Language Acquisition: AnIntegrated Approach to Critical Period Inquiry. Clevedon: Multilingual Matters.

Moyer, A. (2007). Do language attitudes determine accent? A study of bilinguals in the USA. Journal of Multilingual and Multicultural Development, 28(6), 502-518. 
Moyer, A. (2014). What's age got to do with it? Accounting for individual factors in second language accent. Studies in Second Language Learning and Teaching, 4(3), 443-464. DOI: 10.14746/ssllt.2014.4.3.4

O’Malley, J. M., \& Chamot, A. U. (1990). Learning strategies in second language acquisition. Cambridge: Cambridge University Press.

Osburne, A. G. (2003). Pronunciation strategies of advanced ESOL learners. International Review of Applied Linguistics in Language Teaching, 41, 131-143.

Oxford, R. L. (1990). Language learning strategies: What every teacher should know. Boston: Heinle \& Heinle.

Pawlak, M. (2008). Another look at pronunciation learning strategies: An advanced learner's perspective. In E. Waniek-Klimczak (Ed.), Issues in Accents of English (pp. 304-322). Newcastle upon Tyne: Cambridge Scholars Publishing.

Pawlak, M. (2010). Designing and piloting a tool for the measurement of the use of pronunciation learning strategies. Research in Language, 8, 189-202. DOI: 10.2478/v10015-010-0005-6

Pawlak, M. (2011). Students' successes and failures in learning foreign language pronunciation: Insights from diary data. In J. Arabski \& A. Wojtaszek (Eds.), The Acquisition of L2 Phonology (pp. 165-182). Bristol: Multilingual Matters.

Peterson, S. (2000). Pronunciation Learning Strategies: A First Look (ERIC Document Reproduction Service No. ED450599).

Piske, T., MacKay, I. R. A., \& Flege, J. (2001). Factors affecting degree of foreign accent in an L2: a review. Journal of Phonetics, 29, 191-215.

Purcell, E., \& Suter, R. (1980). Predictors of pronunciation accuracy: A re-examination. Language Learning, 30, 271-287.

Reiterer, S. M., Hu, X., Erb, M., Rota, G., Nardo, D., Grodd, W., Ackermann, H. (2011). Individual differences in audio-vocal speech imitation aptitude in late bilinguals: functional neuro-imaging and brain morphology. Frontiers in psychology, 2(271). DOI: $10.3389 /$ fpsyg.2011.00271

Rogerson-Revell, P. (2011). English Phonology and Pronunciation Teaching. London: Continuum International Publishing Group.

Rokoszewska, K. (2012). The influence of pronunciation learning strategies on mastering English vowels. Studies in Second Language Learning and Teaching, 2, 391-413.

Rubin, J. (1975). What the "good learner" can tell us. TESOL Quarterly, 9, 41-51.

Sardegna, V. G., Lee, J., \& Kusey, C. (2014). Development and validation of the learner attitudes and motivations for pronunciation (LAMP) inventory. System, 47, 162-175.

Stern, H. H. (1975). What can we learn from the good language learner? Canadian Modern Language Review, 31, 304-318.

Smit, U. (2002). The interaction of motivation and achievement in advanced EFL pronunciation learners. IRAL, 40, 89-116.

Tominaga, Y. (2009). An analysis of successful pronunciation learners: in search of effective factors in pronunciation teaching. Pan-Pacific Association of Applied Linguistics, 13, 127-140.

Tseng, W., Dörnyei, Z., \& Schmitt, N. (2006). A new approach to assessing strategic learning: The case of self-regulation in vocabulary acquisition. Applied Linguistics, 27, 78-102. 
Wrembel, M. (2003). Rola metakompetencji w akwizycji fonologii języka obcego w świetle badań dotyczących efektywności procesu nauczania wymowy [The role of metacompetence in the acquisition of foreign language phonology in the light of empirical research on effectiveness of pronunciation learning process]. Zeszyt Naukowy Instytutu Neofilologii (2). Zeszyty Naukowe Państwowej Wyższej Szkoty Zawodowej w Koninie, 1, 150-158.

Wrembel, M. (2008). In search of effective strategies for L2 pronunciation teaching and learning. In M. Pawlak (Ed.), Investigating English Language Learning and Teaching (pp. 179-194). Poznań-Kalisz: Wydawnictwo UAM.

Zhang, Q. M. (2009). Affecting factors of native-like pronunciation: A literature review. Unpublished dissertation. Chung-Ang University. Retrieved September 7, 2011, from http://cau.ac.kr/ edusol/see/list/Vol27-2/CAKE027-002-4.pdf 